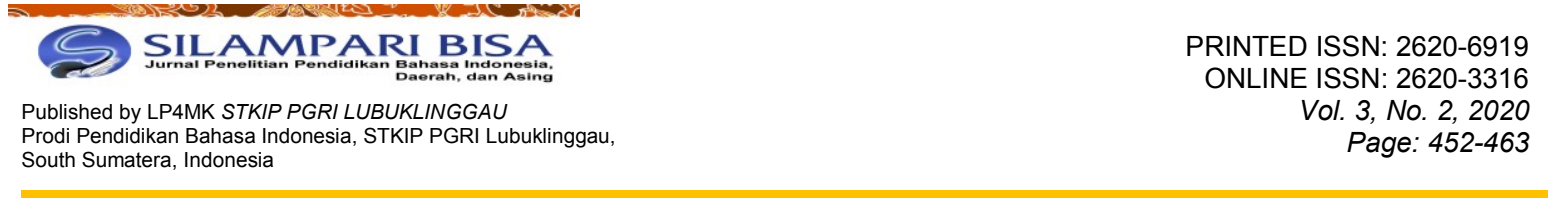

\title{
PENINGKATAN KEMAMPUAN MENULIS TEKS FABEL MENGGUNAKAN MODEL PEMBELAJARAN CREATIVE PROBLEM SOLVING (CPS) SISWA KELAS VII MTS AL-QURAN HARSALLAKUM KOTA BENGKULU
}

\author{
Rilla Wahana ${ }^{1}$, Susetyo ${ }^{2}$, Gumono ${ }^{3}$ \\ ${ }^{1,2,3}$ Program Studi Magister Pendidikan Bahasa Indonesia, Universitas Bengkulu \\ Jln. Wr. Supratman Kandang Limun, Kota Bengkulu, Indonesia \\ Email: rillawahana@gmail.com ${ }^{1}$, testyo55@gmail.com ${ }^{2}$, gumono@unib.ac.id ${ }^{3}$
}

\begin{abstract}
Abstrak
Tujuan penelitian ini mendeskripsikan peningkatan kemampuan menulis teks fabel menggunakan model pembelajaran Creative Problem Solving (CPS) siswa kelas VII MTs AIQuran Harsallakum Kota Bengkulu. Metode penelitian yang digunakan yaitu metode Penelitian Tindakan Kelas (PTK) dengan model Hopkins. Penelitian ini terdiri dari dua siklus, masing-masing siklus terdiri empat tahap yakni, perencanaan, pelaksanaan, pengamatan, dan refleksi. Teknik pengumpulan data menggunakan teknik tes, observasi, dan observasi. Teknik analisis data pada penelitian adalah memberikan nilai atau skor terhadap teks fabel yang ditulis siswa, serta penilaian terhadap aktivitas siswa dan guru dalam pembelajaran menulis teks fabel yang dilakukan peneliti dan teman sejawat. Hasil penelitian menunjukkan terjadi peningkatan aktivitas guru siklus I $87,50 \%$ menjadi $100 \%$. Aktivitas siswa juga mengalami peningkatan pada siklus I berdasarkan pengamatan obeserver yakni sebesar $4,56 \%$ dan penilai sebesar $4,22 \%$. Sedangkan pada kemampuan menulis teks fabel siswa kelas VII.G MTs Al Quran Harsallakum kota Bengkulu mengalami peningkatan dalam menulis teks fabel dengan menggunakan model pembelajaran Creative Problem Solving (CPS), dilihat pada siklus I rata-rata nilai siswa sebesar 73,15 dengan kategori cukup dan meningkat pada siklus II dengan nilai rata-rata sebesar 84,35 kategori baik.
\end{abstract}

Kata kunci: kemampuan menulis, teks fabel, model pembelajaran Creative Problem Solving

\section{IMPROVED ABILITY TO WRITE FABLE TEXTS USING CREATIVE PROBLEM SOLVING (CPS) LEARNING MODELS FOR SEVENTH GRADE STUDENTS OF MTS AL-QURAN HARSALLAKUM BENGKULU CITY}

\begin{abstract}
The purpose of this study was to describe the improvement of the ability to write fable texts using the Creative Problem Solving (CPS) learning model for seventh grade students of MTs Al-Quran Harsallakum Bengkulu City. The research method used is the Classroom Action Research (CAR) method with the Hopkins model. This study consisted of two cycles, each cycle consisting of four stages, namely, planning, implementing, observing, and reflecting. The technique of collecting data uses test, observation, and observation techniques. The data analysis technique in the study was to provide a value or score on the fable text written by students, as well as an assessment of the activities of students and teachers in learning to write fable texts carried out by researchers and peers. The results showed that there was an increase in teacher activity cycle I $87.50 \%$ to $100 \%$. Student activity also increased in the first cycle based on obeserver observations, namely $4.56 \%$ and the rater at $4.22 \%$. Whereas in the ability to write fable text for students of class VII.G MTs Al Quran Harsallakum
\end{abstract}


Bengkulu City experienced an increase in writing fable texts using the Creative Problem Solving (CPS) learning model, seen in cycle I the average score of students was 73.15 with a sufficient category. and increased in cycle II with an average value of 84.35 good category.

Keywords: writing skills, fable text, Creative Problem Solving learning model

\section{A. Pendahuluan}

Pembelajaran bahasa Indonesia menuntut siswa mampu berkomunikasi secara kritis, kreatif, dan inovatif sehingga dibutuhkan penerapan model pembelajaran yang bisa mengaktifkan peran siswa tersebut (Kusmiarti dkk., 2020:207). Guru bahasa Indonesia memiliki peran strategis dalam merencanakan pembelajaran dengan memilih model pembelajaran yang tepat dan sesuai dengan karakter siswa (Noermanzah, 2015:274). Pemilihan model pembelajaran tentunya perlu memahami konsep model pembelajaran dan langkah-langkah model pembelajaran yang akan diterapkan.

Model pembelajaran, yaitu kerangka konseptual yang melukiskan prosedur yang sistematis dalam mengorganisasikan pengalaman belajar untuk mencapai tujuan belajar tertentu, dan berfungsi sebagai pedoman bagi para perancang pembelajaran dan para pengajar dalam merencanakan aktivitas belajar mengajar (Nurulwati, 2000:10 dan Hermanudin dkk., 2019). Dengan demikian, aktivitas pembelajaran benar-benar merupakan kegiatan bertujuan yang tertata secara sistematis.

Berdasarkan hasil studi pendahuluan dengan menggunakan observasi awal terdapat beberapa permasalahan yaitu (1) pelaksanaan pembelajaran kelas VII di MTs Al Quran Harsallakum pada pelajaran Bahasa Indonesia siswa kelas VII masih cenderung bersifat pasif; (2) dalam pembelajaran interaksi guru dan siswa relatif minim, pembelajaran yang digunakan teacher center, guru belum optimal dalam mengarahkan dan melatih kemapuan menulis siswa; (3) nilai siswa dari VII kelas ada satu kelas yakni, kelas VII G keseluruhan kelas VII $60 \%$ masih di bawah kriteria ketuntasan minimal itu dibuktikan dengan adanya remedial; siswa jarang diberikan kesempatan untuk memecahkan masalahnya sendiri, penyampaian konsep pada siswa dalam kegiatan pembelajaran cenderung 
membosankan dan tanpa proses ilmiah yang pada dasarnya semua itu dapat dikembangkan dan dilatih dalam proses pembelajaran bahasa Indonesia.

Maka dari itu, diperlukan suatu inovasi yang baru dalam pembelajaran yang inovatif yaitu dengan menerapkan model pembelajaran yang dapat membangkitkan motivasi siswa untuk meningkatkan kemampuan menulis, khususnya menulis teks fabel. Berdasarkan permasalahan di atas, peneliti mencoba solusi untuk perbaikan dan peningkatan pembelajaran di kelas dengan VII G khususnya dengan menerapkan model pembelajaran creative problem solving (CPS) yang memiliki beberapa kelebihan antara lain: (1) melatih siswa untuk belajar mandiri; (2) ilmu dan pengetahuan yang diperoleh siswa bersifat nyata atau aplikatif; (3) meningkatkan kemampuan analisis siswa; (4) menumbuhkan kebanggaan dalam diri siswa ketika ia berhasil memecahkan masalah yang dihadapi; dan (5) ilmu dan pengetahuan yang diperoleh cendrung bersifat permanen dalam arti melekat dalam ingatan siswa (Rismadewi, 2019:302; Huda, 2017).

Pada penelitian ini peneliti memilih materi kompetensi menulis teks fabel, sesuai dengan standar kompetensi dan kompetensi dasar yang diterapkan di MTs Al Qur'an Harsallakum Kota Bengkulu yang mana standar kompetensi nomor tiga yaitu; memahami, menerapkan, dan menganalisis pengetahuan faktual, konseptual, prosedural, dan metakognitif berdasarkan rasa ingin tahunya tentang ilmu pengetahuan, teknologi, seni, budaya, dan humaniora dengan wawasan kemanusiaan, kebangsaan, kenegaraan, dan peradaban. Kemampuan menulis teks fabel ini diteliti baru sebatas menggunakan modelling the way (Lestari, 2017; metode discovery learning (Filma, 2019), dan teknik think talk write (TTW) (Wahyuni dan Thahar, 2020). Untuk itu, penerapan model creative problem solving (CPS) belum diterapkan pada pembelajaran menulis teks fabel siswa kelas VII MTs AI-Quran Harsallakum Kota Bengkulu.

Terkait penyebab fenomena dan kajian serta menerapkan pengetahuan prosedural pada bidang kajian yang spesifik sesuai dengan bakat dan minatnya untuk memecahkan masalah. Maka penulis tertarik untuk melakukan kajian 
penelitian bidang kemampuan menulis teks fabel melalui penerapan creative problem solving (CPS) dengan tujuan untuk meningkatkan kemampuan menulis siswa. Berdasarkan fakta di atas maka, penelitian berkolaborasi dengan guru untuk melakukan perbaikan pembelajaran menulis teks fabel dengan menggunakan metode penelitian tindakan kelas dengan rumusan masalah bagaimanakah peningkatan kemampuan menulis teks fabel menggunakan model pembelajaran creative problem solving (CPS) pada siswa Kelas VII MTs AI Quran Harsallakum Kota Bengkulu yang dilihat dari peningkatan aktivitas pembelajaran dan kemampuan menulis teks fabel.

\section{B. Metode Penelitian}

Metode penelitian yang digunakan yaitu metode penelitian tindakan kelas (PTK) dengan menggunakan model Hopkins. Pelaksanaan penelitian tindakan kelas memiliki prinsip-prinsip pelaksanaan dengan beberapa prinsip yaitu: (1) PTK dilaksanakan untuk memecahkan masalah yang benar-benar dihadapi dalam proses pembelajaran di kelasnya; (2) pelaksanaan PTK tidak boleh menggangu tugas pokok guru sebagai pendidik yang di dalamnya terdapat kegiatan mengajar, melatih, dan membimbing; (3) pengumpulan data dalam PTK tidak boleh terlalu banyak menyita waktu. Oleh karena itu, guru diharapkan mampu memilih dan menerapkan teknik yang tepat untuk mengumpulkan data yang diperlukan. Kemudian, (4) metodologi yang digunakan dalam PTK jelas dan terpercaya (Susetyo, 2015). Prosedur penelitian tindakan kelas ini mengikuti siklus model Hopkins yang di dalamnya ada empat langkah, yaitu perencaaan, tindakan/pelaksanaan, observasi, dan refleksi (Arikunto, 2006:97).

Teknik pengumpulan data menggunakan teknik tes, observasi, dan dokumentasi. Penelitian ini dilakukan dalam dua siklus, setiap siklus terdiri dari empat langkah yaitu: (1) perencanaan, (2) pelaksanaan pembelajaran, (3) observasi, dan (4) refleksi. Analisis data dilakukan dengan analisis data kuantitatif dan data kualitatif serta uji hipotesis tindakan. Data kuantitatif diperoleh dari analisis hasil tes menulis fabel, tes subjektif pada struktur teks fabel yang meliputi: (1). orientasi, (2). komplikasi, (3). resolusi, (4). koda, dan (5) kaidah kebahasaan. 
Sedangkan data kualitatif diperoleh melalui hasil analisis observasi aktivitas guru dan siswa pada proses pembelajaran. Hipotesis tindakan apabila terjadi peningkatan hasil menulis paragraf dari siklus 1 ke siklus 2 dan hasil aktivitas guru dan siswa dengan kriteria baik. Teknik analisis data dengan menganalisis data kualitatif yaitu data hasil observasi dan dokumentasi, menganalisis data kuantitatif yaitu hasil tes menulis teks fabel, dan kesimpulan.

\section{Hasil Penelitian dan Pembahasan}

\section{Hasil Penelitian}

Model pembelajaran Creative Problem Solving (CPS) meningkatkan kemampuan menulis teks fabel siswa kelas VII G MTs. Al Quran Harsallakum Kota Bengkulu. Hal ini dapat dibuktikan dari hasil tes pada siklus I dengan nilai rata-rata kemampuan menulis teks fabel sebesar $13,06 \%$ atau 3 siswa sangat baik $21,74 \%$ atau 5 siswa berkategori baik $47 \%$ atau 11 siswa cukup dan $17,39 \%$ atau 4 siswa kurang. Kemampuan menulis siswa pada siklus II dengan nilai ratarata sebesar $43,48 \%$ atau 10 siswa kategori sangat baik $56,52 \%$ atau 13 siswa kategori baik.

Model pembelajaran Creative Problem Solving (CPS) juga mampu meningkatkan aktivitas siswa yang mana pada siklus I persentase aktivitas siswa yang dicapai observer pada siklus I sebesar 166 dan siklus II 174 dengan selisih skor 8 dan presentase mengalami peningkatan sebesar $4,56 \%$. Sedangkan jumlah skor yang dicapai penilai atau penelitii pada siklus I sebesar 159 dan siklus II sebesar 166 dengan selisih skor 7 dan presentase mengalami peningkatan sebesar $4,21 \%$.

\section{Pembahasan}

Berdasarkan hasil analisis data, ada beberapa temuan penelitian yang perlu dibahas lebih lanjut, sehingga temuan-temuan tersebut dapat dijadikan rujukan sebagai perbaikan dan peningkatan kualitas pembelajaran. Temuan penelitian tersebut meliputi aktivitas belajar siswa selama proses pembelajaran menulis 
cerita fabel dengan menggunakan model pembelajaran creative problem solving (CPS) dan hasil kemampuan menulis teks fabel siswa. Peningkatan kemampuan menulis teks fabel dengan menggunakan teknik pemodelan pada siswa kelas VII.G MTs Al Quran Harsallakum kota Bengkulu, dapat dilihat pada uraian di bawah ini.

Pada bagian ini akan disajikan presentase peningkatan proses aktivitas guru siklus I ke siklus II dan presentase peningkatan proses aktivitas siswa siklus I dan II pada pembelajaran menulis teks fabel menggunakan model pembelajaran creative problem solving (CPS) dijelaskan sebagai berikut.

\section{a. Presentase Peningkatan Proses Aktivitas Guru Siklus I ke Siklus II}

Berdasarkan hasil perhitungan skor observasi aktivitas guru yang didapatkan pada saat pelaksanaan pembelajaran menulisteks fabel menggunakan model creative problem solving (CPS) siklus I dan II. Pada bagian ini akan disajikan seilisih skor serta peningkatan persen (\%) proses aktivitas siswa siklus I ke siklus Il pada tabel 1 sebagai berikut.

Tabel 1. Presentase Peningkatan Aktlvitas Guru Siklus I ke Siklus II

\begin{tabular}{ccccc}
\hline \multirow{2}{*}{ Aspek } & \multicolumn{3}{c}{ Presentase yang Dicapai } & Persentase \\
\cline { 2 - 3 } & Siklus I & Siklus II & Selisih Skor & Peningkatan \\
\hline Observer & $87,50 \%$ & $100 \%$ & $12,50 \%$ & $12,50 \%$ \\
\hline
\end{tabular}

Berdasarkan table 1 di atas, tentang peningkatan proses aktivitas guru dalam pembelajaran menulis teks fabel menggunakan model pembelajaran creative problem solving (CPS). Dapat diketahui bahwa terjadi peningkatan dari siklus I ke siklus II. Adapun presentase jumlah skor yang dicapai pada siklus I observersebesar $87,50 \%$ meningkat menjadi $100 \%$ pada siklus II. Selisih skor antara siklus I ke siklus II yakni 12,50\%, dengan presentase peningkatan yang terjadi dari siklus I ke siklus I| sebesar $12,50 \%$.

Berdasarkan pembahasan di atas, berikut diuraikan penyebab terjadinya peningkatan terhadap proses aktivitas mengajar guru di sekolah. Salah satu penyebab peningkatan aktivitas dalam pembelajaran menulis fabel menggunakan 
model pembelajaran creative problem solving (CPS) yaitu: (1) guru telah melaksanakan kegiatan pembelajaran menulis teks fabel menggunakan model pembelajarancreative problem solving (CPS) dengan maksimal, (2) guru lebih mudah mengarahkan kegiatan pembelajaran siswa dengan memanfaatkan model pembelajaran creative problem solving (CPS) sebagai alat bantu untuk meningkatan hasil belajar siswa (3) guru lebih banyak memberikan contoh video/gambar dengan menggunakan LCD I infocus mengenal teks fabel. (4) guru berhasil merangsang minat, motivasi, dan menumbuhkan rasa percaya diri siswa dalam kegiatan pembelajaran menulis fabel menggunakan model pembelajarancreative problem solving (CPS). Rismadewi (2019) mengungkapkan bahwa model CPS menekankan keseimbangan antara pemikiran divergen dan konvergen dalam langkah pemecahan masalah. Kemudian, Pepkin (2004:1) juga menyatakan model ini dapat membantu siswa dalam mengembangkan kompetensi stategisnya.

\section{b. Presentase Peningkatan Proses Aktivitas Siswa Siklus I ke Siklus II}

Berdasarkan hasil perhitungan skor observasi aktivitas keaktifan siswa yang didapatkan pada saat pelaksanaan pembelajaran menulis fabel model pembelajaran creative problem solving (CPS) siklus I dan II. Pada bagian ini akan disajikan selisih skor serta peningkatan persen (\%) proses aktivitas siswa siklus I ke siklus Ilpada tabel 2 berikut.

Tabel 2. Persentase Peningkatan Aktivitas Siswa

Siklus I ke Siklus II

\begin{tabular}{lcccc}
\hline \multirow{2}{*}{ Aspek } & \multicolumn{2}{c}{ Persentase jumlah skor yang tercapai } & Persen \% \\
\cline { 2 - 4 } & Siklus I & Siklus II & Selisih Skor & Peningkatan \\
\hline Observer & 166 & 174 & 8 & $4,56 \%$ \\
\hline Penilai & 159 & 166 & 7 & $4,22 \%$ \\
\hline
\end{tabular}

Berdasarkan tabel 2 di atas tentang peningkatan proses aktivitas siswa dalam pembelajaran menulis fabel menggunakan model creative problem solving (CPS). Dapat diketahui bahwa terjadi peningkatan dari siklus I ke siklus II. Adapun jumlah skor yang dicapai obeserver pada siklus I sebesar 166 dan siklus II 
sebesar 174 dengan selisih skor 8 dan presentase mengalami peningkatan sebesar $4,56 \%$. Sedangkan jumlah skor yang dicapai penilai pada siklus I sebesar 159 dan siklus II sebesar 166 dengan selisih skor 7 dan presentase mengalami peningkatan sebesar $4,21 \%$.

Berdasarkan pembahasan di atas, berikut diuraikan penyebab terjadinya peningkatan terhadap proses aktivitas mengajar guru di sekolah. Salah satu penyebab peningkatan aktivitas dalam pembelajaran menulis teks fabel menggunakan model pembelajaran creative problem solving (CPS) yaitu: (1) siswa mampu mengaplikasikan dengan baik penggunaan model creative problem solving (CPS) dalam pembelajaran menulis teks fabel, (2) siswa lebih percaya diri dan terampil menulis teks fabel, (3) minat dan motivasi belajar siswa meningkat sehingga menumbuhkan perubahan signifikan terhadap tingkah laku siswa. Oleh karena itu, media LCD/infocus serta media gambar, dan model pembelajaran yang inovatif menjadi alternatif yang dapat dipilih untuk meningkatkan mutu proses pembelajaran.

Peningkatan aktivitas siswa dalam pembelajaran menulis teks fabel tersebut dapat dipengaruhi beberapa faktor salah satunya siswa lebih antusias belajar karena tertarik dengan teknik pembelajaran yang digunakan guru, terutama jika teknik tersebut belum pernah atau jarang digunakan oleh guru. Dengan menerapkan teknik pemodelan dengan menggunakan media infokus siswa sangat antusias dan bersemangat dalam proses pembelajaran menulis teks fabel. Hal ini didukung pendapat (Rismadewi, 2019) yang menyatakan CPS model pembelajaran dengan pemusatan pada proses belajar dan pembelajaran, keterampilan dalam memecahkan masalah diikuti penguatan keterampilan. Kemudian, Mariana (2010:52) dan Pramestika dkk., (2020) menjelaskan CPS tantangannya mengidentifikasi dalam perjalanan prosesnya untuk menghasilkan ide-ide serta mengimplementasikan solusi yang bersifat inovatif dalam menghasilkan produk yang berbeda dari biasanya.

Berdasarkan data hasil belajar siswa, dapat diketahui bahwa kemampuan siswa dalam pembelajaran menulis teks fabel menggunakan model pembelajaran creative problem solving (CPS) mengalami peningkatan. Peningkatan aktivitas 
siswa ataupun hasil belajar siswa dalam pembelajaran menulis teks fabel dapat dipengaruhi beberapa faktor salah satunya siswa lebih antusias belajar karena tertarik dengan model pembelajaran yang digunakan guru, terutama jika model tersebut belum pernah atau jarang digunakan oleh guru. Dengan menerapkan model pembelajaran creative problem solving (CPS) dan alat bantu pada saat pembelajaran menggunakan LCD/infocus siswa sangat antusias dan bersemangat dalam proses pembelajaran menulis teks fabel.

Hasil analisis siswa yang dilakukan oleh peneliti dan kolaborator dari siklus I ke siklus II mengalami peningkatan, terlihat pada data di atas. Oleh karena itu, dapat disimpulkan bahwa hasil pembelajaran menulis teks fabel menggunakan model pembelajaran creative problem solving (CPS) siswa kelas VII GMTs AI Quran Harsallakum kota Bengkulu mengalami peningkatan keaktifan belajar siswa dari siklus I ke siklus II.

\section{c. Rekapitu|asi Peningkatan Kemampuan Menulis Fabel dari Siklus I ke Siklus II}

Berdasarkan hasil evaluasi terhadap pembelajaran menulis teks fabel, dapat dikatakan bahwa siswa ikut berperan aktif selama kegiatan belajar mengajar berlangsung. Nilai hasil kemampuan menulis teks fable yang diperoleh siswa pada tindakan siklus I masih jauh dari nilai maksimum yang kemungkinan bisa dicapai oleh siswa pada pembelajaran menulis teks fabel. Dari hasil menulis teks fabel siswa pada siklus I ini masih terdapat banyak kekurangan yang harus disempurnakan, sedangkan nilai yang diperoleh siswa pada siklus II sudah sangat baik walaupun belum mencapai skor maksimum. Tamrin (2012:40) dalam penelitiannya menyimpulkan bahwa dalam pelaksaaan CPS menunjukkan adanya perbedaan hasil belajar pada kelas dengan menggunakan model CPS dibandingkan kelas konvensional dan dapat meningkatkan hasil belajar siswa. Adapun data rekapitulasi penmgkatan kemampuan menulis fabel menggunakan model pembelajaran creative problem solving (CPS) siswa kelas VII. G MTs AI Quran Harsallakum dari siklus I ke siklus II dapat dilihat pada tabel 3 sebagai berikut. 
Tabel 3. Rekapitulasi Peningkatan Kemampuan Menulis Fabel Siklus I ke Siklus II

\begin{tabular}{|c|c|c|c|c|c|c|c|}
\hline \multicolumn{3}{|c|}{ Peneliti } & \multirow[b]{2}{*}{$\begin{array}{c}\text { Peningkatan } \\
(\%)\end{array}$} & \multicolumn{3}{|c|}{ Observer } & \multirow[b]{2}{*}{$\begin{array}{c}\text { Peningkatan } \\
(\%)\end{array}$} \\
\hline Juml & Jilai yan & icapai & & Jumlal & Vilai yan & Dicapai & \\
\hline $\begin{array}{c}\text { Siklus } \\
\text { I }\end{array}$ & $\begin{array}{c}\text { Siklus } \\
\|\end{array}$ & $\begin{array}{c}\text { Selisih } \\
\text { Skor }\end{array}$ & & $\begin{array}{c}\text { Siklus } \\
\text { I }\end{array}$ & $\begin{array}{c}\text { Siklus } \\
\text { II }\end{array}$ & $\begin{array}{c}\text { Selisih } \\
\text { Skor }\end{array}$ & \\
\hline 1715 & 1985 & 270 & $15,74 \%$ & 1650 & 1895 & 245 & $14,85 \%$ \\
\hline
\end{tabular}

Berdasarkan tabel di atas, diketahui bahwa yang dilakukan peneliti pada saat siklus I jumlah nilai di dapat secara keseluruhan 1715 sedangkan untuk siklus II jumlah nilai yang didapat secara keseluruhan yakni 1985 dengan selisih skor dari siklus I ke siklus || yakni 270. Dari siklus I ke siklus IImengalami peningkatan mencapai $15,74 \%$. Diketahui bahwa yang evaluasi yang dilakukan observer pada saat siklus I jumlah nilai di dapat secara keseluruhan yakni 1650. Sedangkan untuk siklus II jumlah nilai yang di dapat secara keseluruhan yakni 1895. Selisih skor dan siklus I ke siklus || yakni 245. Dari siklus I ke siklus || mengalami peningkatan mencapai $14,85 \%$.

\section{Simpulan dan Saran}

Penerapan model pembelajaran creative problem solving (CPS) sebagai model pembelajaran telah mampu meningkatkan proses aktivitas siswa dan guru serta dan hasil pembelajaran menulis teks fabel siswa kelas VII.G MTs AI Quran Harsallakum. Peningkatan proses aktivitas siswa dari pengamat 1 dan 2 nilai pengamatan aktivitas siswa sudah ada peningkatan. Untuk pengamat 1 terjadi peningkatan pada aktivitas siswa mengerjakan tugas dengan serius sebesar $8,7 \%$, menyimak penjelasan guru $8,7 \%$ dan tidak mencontoh karya siswa sebesar $8,7 \%$. Sedangkan pada pengamatan pengamat II terjadi peningkatan pada aktivitas guru yakni pada aktivitas siswa mengerjakan tugas dengan serius sebesar $4,3 \%$, berdiskusi dengan kelompok $17,39 \%$, dan tidak mencontoh karya teman.

Pada proses aktivitas guru terjadi peningkatan dalam aktivitas guru terjadi peningkatan sebesar $12,5 \%$ dari siklus I ke siklus II. Hasil belajar menulis fabel menggunakan model pembelajaran creative problem solving (CPS) siswa kelas 
VII.G MTs AI Quran Harsallakum ketuntasan belajar siswa dapat diketahui bahwa perbandingan ketuntasan hasil belajar siswa dalam pembelajaran menulis fabel siklus II yaitu jumlah siswa yang tuntas sebanyak 21 siswa atau sekitar 91,30\%, sedangkan siswa yang tidak tuntas sebanyak 2 siswa atau sekitar $8,7 \%$.

Penelitian dari kolaborator juga dapat diketahui bahwa perbandingan ketuntasan hasil belajar siswa dalam pembelajaran menulis teks fabel siklus II yaitu jumlah siswa yang tuntas sebanyak 18 siswa atau sekitar 78,26\%, sedangkan siswa yang tidak tuntas sebanyak 5 siswa atau sekitar 21,74\%. Hal tersebut menunjukkan bahwa telah terjadi peningkatan terhadap hasil belajar siswa, aktivitas guru, dan aktivitas siswa. Untuk itu, model creative problem solving (CPS) diharapkan dapat dijadikan alternatif bagi guru dalam meningkatkan kemampuan menulis teks fabel dan bisa juga pada materi yang lain yang memiliki karakter kompetensi dasar yang sama.

\section{Daftar Pustaka}

Arikunto, S. (2006). Prosedur Penelitian Suatu Pendekatan Praktek. Jakarta: PT. Rineka Cipta.

Filma, F. (2019). Peningkatan Kemampuan Menulis Teks Fabel Menggunakan Metode Discovery Learning SMP Negeri 8 Pontianak. Jurnal Edukasi Khatulistiwa, 2(1), 11. doi:10.26418/ekha.v1i1.31567

Hermanudin, Suhartono, Suryadi, \& Noermanzah. (2019). Improvement of Reading Comprehension Ability by Using Core Models of Class VII a Students of SMP Negeri 10 Bengkulu Tengah. International Journal of Scientific and Technology Research, 8(12). http://www.ijstr.org/paperreferences.php?ref=|JSTR-1219-25902

Huda, F. A. (2017). Pengertian Model Pembelajaran Creative Problem Solving. fatkan.web.ID , 1.

Kusmiarti, R., Yuniati, I., \& Noermanzah. (2020). Improving Student Communication Skills In Learning Indonesian Language Through Collaborative Learning. Retrieved from osf.io/9km3u. International Journal of Scientific and Technology Research, 9(1). 
Lestari P., O. (2017). Pengaruh Modelling The Way terhadap Kemampuan Menulis Teks Cerita Fabel Siswa SMP. RETORIKA: Jurnal Bahasa, Sastra, dan Pengajarannya, 10(2), 89. doi:10.26858/retorika.v10i2.4854

Mariana, D. (2010). Pengaruh Metode Pembelajaran Creative Problem Solving (CPS) terhadap Peningkatan Kemampuan Berpikir Kreatif Siswa: Studi Eksperimen Mata Pelajaran IPS Kelas VII Pokok Bahasan Kreativitas dalam Tindakan Ekonomi di SMP Negeri 143 Jakarta Utara. Tesis: UPI. Bandung: tidak diterbitkan.

Noermanzah, N. (2015). Peran Dosen Bahasa dan Sastra Indonesia dalam Mempertahankan Bahasa Indonesia sebagai Alat Pemersatu Negara Kesatuan Republik Indonesia pada Era Globalisasi. In Prosiding Seminar Nasional Bulan Bahasa 2015. Unit Penerbitan FKIP Universitas Bengkulu, p. 274. http://repository.unib.ac.id/11133/

Nurulwati (2000). Pengertian Pendekatan Strategi, Metode, Teknik, Taktik dan Model Pembelajaran. http://tricepti4042.blogspot.com (Diakses tanggal 10 Maret 2020).

Pepkin. (2004). Creative Problem Solving in Math. http://www.mathematic.transdigit.com/matematic-journal.html.

Pramestika, R, A ., Suwignyo, H \&Utaya, S. (2020). Model Pembelajaran Creative Problem Solvingpada Kemampuan Berpikir Kreatif dan Hasil Belajar Tematik Siswa Sekolah Dasar. Jurnal Pendidikan, 5(3), 361-366

Rismadewi, N. W. M. (2019). Penerapan Model Creative Problem Solving pada Guru sebagai Upaya Meningkatkan Prestasi Belajar Siswa pada Mata Pelajaran Bahasa Inggris. Indonesian Journal Of Educational Research and Review, 2(3), 302. doi:10.23887/ijerr.v2i3.23217

Susetyo. (2015). Penelitian Kuantitatif dan Penelitian Tindakan Kelas. Bengkulu: Unit Penerbitan FKIP Universitas Bengkulu.

Tamrin, M. (2012). Efektivitas Model Pembelajaran Creative Problem Solving (CPS) dalam Meningkatkan Hasil Belajar Siswa pada Materi Limit Fungsi Aljabar. (Online).http://id.portalgaruda/ daorg/?ref=browse\&mod= viewarticle\&article=455962. Pdf.PadaTanggal02Januari2018.

Wahyuni, N. D., \& Thahar, H. E. (2020). Pengaruh Teknik Pembelajaran Think Talk Write (TTW) Berbantuan Media Gambar Berseri terhadap Keterampilan Menulis Teks Fabel. Pendidikan Bahasa Indonesia, 8(5), 290. doi:10.24036/108212-019883 